\title{
Cross-cultural differences in visual attention: a computational modelling study
}

\author{
Eirini Mavritsaki ${ }^{1,2^{*}}$, Panagiotis Rentzelas ${ }^{1}$ \\ From 24th Annual Computational Neuroscience Meeting: CNS*2015 \\ Prague, Czech Republic. 18-23 July 2015
}

Literature in visual perception has identified that there are cross-cultural differences in visual perception [1]. Research comparing members of interdepended and collectivist East Asian cultures with independent and individualist European American cultures into picture perception showed that East Asians are more likely to attend the perceptual field as a whole and to focus on context and Westerns to focus on the salient foreground objects [1]. Research on cross-cultural differences has focused on investigating cross-cultural differences related to bottom-up information. Furthermore, research that experimentally manipulated the cultural norms of individualism and collectivism groups managed to attenuate cultural-specific preferences for social factors beneficial in human motivation [2]. Investigating the underlying mechanisms involved in these differences is very important as it can affect everyday tasks, advertisement and many other aspects of our everyday life.

Here we present the first steps of this work, investigating the underlying processes in cross-cultural differences using computational modelling studies. The computational model is based on the spiking Search over Space and Time (sSoTS) model [3], that has been used to simulate Visual Attention task. sSoTS has incorporated mechanisms that allows us to investigate both bottomup and top-down processes. We show that sSoTS can successfully simulate cross-cultural differences in Visual attention involving bottom-up tasks. Moreover, we expand the studies by making predictions from the computational modelling studies for cross-cultural differences and top-down tasks.

\footnotetext{
* Correspondence: eirini.mavritsaki@bcu.ac.uk

'Department of Psychology, Birmingham City University, Birmingham, B422SU, UK

Full list of author information is available at the end of the article
}

\section{Acknowledgements}

The authors would like to acknowledge the use of the Advanced Research Computing (ARC) in carrying out this work.

\section{Authors' details}

'Department of Psychology, Birmingham City University, Birmingham, B422SU, UK. ${ }^{2}$ Department of Experimental Psychology, University of Oxford, Oxford, OX1 3UD, UK.

\section{Published: 18 December 2015}

\section{References}

1. Miyamoto $Y$, Nisbett RE, Masuda T: Culture and the physical environment - Holistic versus analytic perceptual affordances. Psychological Science 2006, 17(2):113-119.

2. Hagger MS, Rentzelas P, Chatzisarantis NLD: Effects of individualist and collectivist group norms and choice on intrinsic motivation. Motivation and Emotion 2014, 38(2):215-223.

3. Mavritsaki E, et al: Bridging the Gap Between Physiology and Behavior: Evidence From the sSoTS Model of Human Visual Attention. Psychological Review 2011, 118(1):3-41.

\section{doi:10.1186/1471-2202-16-S1-P204}

Cite this article as: Mavritsaki and Rentzelas: Cross-cultural differences in visual attention: a computational modelling study. BMC Neuroscience 2015 16(Suppl 1):P204.

\section{Submit your next manuscript to BioMed Central and take full advantage of: \\ - Convenient online submission \\ - Thorough peer review \\ - No space constraints or color figure charges \\ - Immediate publication on acceptance \\ - Inclusion in PubMed, CAS, Scopus and Google Scholar \\ - Research which is freely available for redistribution

() Biomed Central

(C) 2015 Mavritsaki and Rentzelas This is an Open Access article distributed under the terms of the Creative Commons Attribution License (http://creativecommons.org/licenses/by/4.0), which permits unrestricted use, distribution, and reproduction in any medium, provided the original work is properly cited. The Creative Commons Public Domain Dedication waiver (http://creativecommons.org/ publicdomain/zero/1.0/) applies to the data made available in this article, unless otherwise stated. 